\author{
Francisco José Lería Dulčić ${ }^{1}$, Roxana Nora Acosta Peña ${ }^{2}$, Patricia Ester Sasso \\ Orellana ${ }^{1}$, Daniela Andrea Collao Jofré ${ }^{1}$ \\ ${ }^{1}$ University of Atacama, ${ }^{2}$ University of Antofagasta \\ francisco.leria@uda.cl,roxana.acosta@uantof.cl,patricia.sasso@uda.cl,daniela.collao@uda.cl
}

\title{
Do instructions overwhelm the preschool classroom? Early childhood educators' use of instructional vs regulative directive commands
}

\begin{abstract}
Instructions are a fundamental part of early childhood educators' verbal activities in a plethora of interactions, that constantly guide children to achieve a targeted educational goal. However, little attention has been devoted to identify their presence and relative proportions in early childhood educators' daily speech. Underpinned by functional linguistic theory, this study's purpose is to identify early childhood educators' spoken directive commands from a large database to check their distribution and predominance, compared to other verbal modalities that are equally important for their pedagogical work, such as: commands, sayings, feedback, questions, etc. Through 20 participants' daily audio-recordings from regular work-hours with preschool children, we selected a large number of sentences to later be classified according to their degree of belonging to a specific directive command's category - ten in this study. The findings suggest that instructional directives are the first in order of frequency followed by the use of reformulations and singing, among others. We conclude that it is vital for early childhood educators' professional practice to identify which types of linguistic styles they predominantly use in order to make effective decisions to pursuit an educational goal, and that way successfully support young children's learning processes. The scope of these findings is briefly discussed taking into perspective future research and its contributions to early childhood education's formative processes.
\end{abstract}

\section{Introduction}

Five decades of well-documented research has made a strong case about the specific role of teachers' linguistic responsivity to students' learning demands (Justice et al. 2018; Prediger 2019), mostly due to its supportive function on students' language development (Markussen-Brown et al. 2017), and psychosocial development (Kalinowski et al. 2020). Within this line of research, several features of 
teachers' linguistic ability have been distinguished, one of them reaching its academic and disciplinary status. Schleppegrell (2012) characterizes this specific use of language as a phenomenon with a more complex syntax, precise vocabulary, greater word number, sophisticated sentences, and a larger lexical variety. When utilized inside the classroom, this specific and specialized use of language is commonly divided into two general types: regulative and instructional (Christie 2005). According to Chen (2017), teachers encompass both of them, through the knowledge that is transferred to students and the simultaneous management of the social environment in the classroom. This distinction is up to a certain degree diffuse in consideration of an instructional style as being at the same time equally interpretable as an imperative command and a procedure that shape children's behaviours, therefore, as is stated by Cazden (2001), teacher discourse reflects a dual role as subject instructor and manager of the classroom, responsible by both means for initiating students into the act of learning and behaving.

Even though early research unanimously concluded that the effect of directive instructional environments on children development is an undesirable one (Aikhenvald 2010), nowadays it had been shown that the scope of these conclusions depends upon many factors with sometimes opposite effects. Up-to-date evidence exposes that these kinds of environments have a broad range of effects on a variety of children's behavioural and learning outcomes. This is well-summarized by Medina and Sobel (2019), who state that children better develop specific cognitive abilities, such as a causal system of explanation, from caregivers who are more directive in their verbal interactions than hands-off ones that frequently allow children to engage in unstructured exploration. In this vein, recent research examines the role of instructional language in the development of children's memory and cognitive skills (Ornstein and Coffman 2020), and also the influence of various ECEs' linguistic strategies with an affective connotation (e.g.: validate feelings, provide choices, demonstrate love, and others), on succeeding in redirecting child behaviour, solving inter-personal conflicts, and improving teacher-child relationships (Haslip et al. 2018). As a result, a profound influence of teachers' linguistic response on specific aspects of children's cognitive development - for example on working memory - is suggested (Van Loon and Roebers 2020), recognizing the necessary attention that must be given to teachers' instructional strategies mastery as a relevant factor for the improvement of quality in-classroom practices (Gerde et al. 2018).

Early childhood education embodies a key context from which children develop through all verbal and non-verbal communication that they receive on a regular basis from their educators. Therefore, the nature, purpose, and effectiveness of early childhood educators' (hereinafter ECEs) verbal competence and use of instructional language have been explored from a range of perspectives. As asserted by Piasta and co-researchers (2019), ECEs' language and literacy competence are considered an important factor in conducting classroom practices and thereby supporting children's early language and literacy development. Farrow, Wasik, and 
Hindman (2020) also highlight the meaningful relation between the complexity of ECEs' syntax and children's vocabulary development, suggesting that the use of complex syntax is an important source of linguistic information for learners of new words, as well as the quantity, syntactic complexity and lexical diversity of ECEs speech to children in different classroom situations (Pizarro et al. 2019). Specific cognitive abilities are stimulated as well by ECEs' verbal competence and teaching ability, such as print concept, letter naming, and/or phonological abilities, indicating that greater levels of ECEs' knowledge are associated to more desirable classroom language and literacy practices (Ciesielski and Creaghead 2020). In regard to the study of instructional language, two relevant studies are worth highlighting here. Hu and co-researchers (2017) have shown that nonsuggestive commands and - on the contrary - direct commands are simultaneously the most commonly ECEs' verbal approaches when speaking to infants, with an observed difference between university-qualified ECEs who used significantly fewer nonsuggestive and direct commands than diploma and certificate-qualified educators did. Martí and Portolés (2019) have pinpointed to what extent pre-school practitioners' linguistic choices have an impact on providing rich pragmatic verbal inputs and creating a good social rapport with children, which shows that these choices are modulated by the degree of directness, addition of peripheral modifiers, use of person deixis and co-occurring speech acts in teachers' feedback, such as praise or criticism, among many others.

\section{Theoretical background}

The present study rests on one of the core concepts of the paradigmatic dimension of functional linguistics, which claims the meaning of words lies, as Halliday argues (2014), in a vast network of interrelated choices. Thus, choice plays an axiomatic role under the notion that picking a linguistic unit is given at any moment in a range of available options to the person (Halliday 1976). Matthiessen, Teruya and Lam (2010), add to the understanding of this concept that choosing in a linguistic system is widely determined by three general aspects: (a) what the option realizes (the view "from above" or its signification), (b) what the option is realized by (the view "from below"), and (c) what other options contrasts with (the view "from roundabout" or systemic value). In this study we specifically address the concept of choice through a micro-perspectival approach as proposed by Martínez-Insua (2004, as cited in Fontaine, Bartlett and O'Grady 2013), by considering its occurrence in a text and/or narration according to: (a) a given context; ( $b$ ) a given output; and $(c)$ a given probability. This model approaches the linguistic phenomena in a specific form and is strongly related to the study of grammar, permitting a theoretical order to scrutinized linguistic data. Nonetheless, it can be helpful to contextualize the information that is analyzed our study. Following the dimensions mentioned above, the context in our research is indicated by the whole speech that ECEs produce in a daily educational environment and commonly marked by a spe- 
cific, simple, adapted, but non-colloquial use of language when communicating to young children. The linguistic output is given by all speech forms that imply a command that addresses and directs children to behave in certain ways - ten of them in this study. Finally, the probability of occurrence is limited to the percentages of directives commands' totals, which give an initial hint about its probability of occurrence in ECEs' overall speech.

\section{ECEs' linguistic styles}

A closer look at this term shows scattered information with many branches and variated theoretical definitions that much depend upon the disciplinary or scientific field that is being covered. Within developmental psychology, this term originally comes out from the study of communication in mother-baby early interactive episodes, considering ongoing phenomena like intentionality, joint attention, and inter-subjective exchanges. Furthermore, it is broadly shared that language and subsequently meaning in a sentence is grounded in a sensory-motor and social interactive experience (Fischer 2010), that encompasses, according to Hinojosa and co-researchers (2019): “(...) a complex set of semantic features in a distributed sensory, motor, language, and affective networks in the brain (...)" (p. 1). Thus, available evidence appeals to the role of ECEs' verbal competence, and, as it has already been mentioned above, the engagement of children's development on various learning outcomes, for instance, the kind of questions teachers pose to children (Chen and Liang 2016), the quality of ECEs' words in playing activities (Wasik and Jacobi-Vessels 2017), and/or how long they speak directly to a child (Torr and Pham 2016). This influence has also been related to ECEs' teaching experience negatively associated with the frequency of instructional talk (Schachter et al. 2016), or to more complex linguistic behaviours as in the case of minimalizing language, a kind that purposefully distances them from the child's current emotions, with a detrimental influence on children's social and emotional competence development (King and La Paro 2018).

The present study understands a linguistic style as a group of verbal utterances that make a specific talk distinguishable, and imply a statement that command a person to act. This term is situated under the assumption that the characteristic speech of a person is given by the type of words that he/she generally uses when speaking, having at the base a notion of performative language (Reyes et al. 2008). In other words, the linguistic style of each of the actors in an educational environment, as well as allowing the communication of content by the speaking, also allows influencing the other and configuring new realities. According to Aikhenvald (2010), it has an explicit affective factor that is brought into verbal interaction by the speaker, also known as "a grammatical mood". The conceptual framework of the research conducted by Simões de Oliveira, de Sousa Braz-Aquino, and Ribeiro Salomão (2016), Nunes and Aquino (2014), and Aquino and Salomão $(2011,2005)$ was considered in our work to address different linguistic features of adult-child 
communication. Therefore, ten directive commands were selected, covering those of an imperative character, though others more focused on regulative linguistic strategies (Table 1).

\begin{tabular}{|c|c|c|}
\hline & Directives* & Brief definitions \\
\hline \multirow[t]{3}{*}{$\begin{array}{l}\text { Directives of } \\
\text { instructional } \\
\text { nature }\end{array}$} & $\begin{array}{l}\text { Attentional } \\
\text { directives (AD) }\end{array}$ & $\begin{array}{l}\text { Statements in which the adult has the pur- } \\
\text { pose of drawing the child's attention, asking } \\
\text { him to approach or look at something, e.g.: } \\
\text { look at Ana, take, look, and arrive. }\end{array}$ \\
\hline & $\begin{array}{l}\text { Control directives } \\
\text { (CD) }\end{array}$ & $\begin{array}{l}\text { The adult expresses objection to the child's } \\
\text { behaviour, e.g.: leave the chair. }\end{array}$ \\
\hline & $\begin{array}{l}\text { Instructional } \\
\text { directives (ID) }\end{array}$ & $\begin{array}{l}\text { The adult provides information to the child } \\
\text { regarding an activity or object, e.g.: go Ana, } \\
\text { hold out your hand. Also, Teacher encou- } \\
\text { rages verbal communication by linking } \\
\text { comments to invite children to take turns, } \\
\text { balancing the number and length of adult to } \\
\text { child turns, and using sentence completion } \\
\text { with children. }\end{array}$ \\
\hline \multirow[t]{7}{*}{$\begin{array}{l}\text { Directives of } \\
\text { a regulative } \\
\text { nature }\end{array}$} & $\begin{array}{l}\text { General feedback } \\
\text { (GF) }\end{array}$ & $\begin{array}{l}\text { Statements that imply giving back informa- } \\
\text { tion to the child that does not directly su- } \\
\text { ggest approval or disapproval observations. }\end{array}$ \\
\hline & $\begin{array}{l}\text { Approval feedback } \\
\text { (AF) }\end{array}$ & $\begin{array}{l}\text { Statements of approval or disapproval in } \\
\text { relation to the child's behaviour. }\end{array}$ \\
\hline & $\begin{array}{l}\text { Disapproval } \\
\text { feedback (DF) }\end{array}$ & $\begin{array}{l}\text { The adult verbalizes his approval of the } \\
\text { child's verbal and non-verbal behaviour. }\end{array}$ \\
\hline & $\begin{array}{l}\text { Use of assertive } \\
\text { expressions (AE) }\end{array}$ & $\begin{array}{l}\text { The adult verbally expresses that what the } \\
\text { child did or said is incorrect, ex: no Daniel, } \\
\text { leave the chair here. }\end{array}$ \\
\hline & $\begin{array}{l}\text { Use of } \\
\text { reformulations }(\mathrm{R})\end{array}$ & $\begin{array}{l}\text { Enunciated with the intention of descri- } \\
\text { bing observable aspects, e.g.: it is a car. } \\
\text { Teacher provides information related to } \\
\text { the children's topics or the ongoing activity } \\
\text { by using comments to inform, project, pre- } \\
\text { tend/imagine, explain, talk about the future, } \\
\text { talk about feelings. }\end{array}$ \\
\hline & Request usage (RU) & $\begin{array}{l}\text { The adult repeating, modifying, enriching or } \\
\text { correcting the child's statement. }\end{array}$ \\
\hline & Singing $(S)$ & The adult sings a song for the child. \\
\hline
\end{tabular}

Table 1. List of selected directive commands 


\section{Current study}

According to the Subsecretary of Initial Education, the regions where this study was undertaken (two nearby cities in northern Chile), had, until August 2020, a sum of 1,588 ECEs working in establishments that are government-dependent, with a significant number working in private centres with official state recognition (Subsecretary of Initial Education [SIE] 2019). In recent years, various instruments have tried to guarantee quality standards for ECEs' professional work, and within them, several technical recommendations have been arranged related to the use of disciplinary language (SIE 2019). Thus, the recognized role of ECEs' verbal competence prompted the researchers to expand a prior study on a quantitative characterization of ECEs' production of socio-affective words (Lería Dulčić et al. in press), to take advantage of a large database and explore the proportions of several linguistic styles or typical phrasings in ECEs' professional speech. By these means it is expected to contribute to the line of research followed by Martí and Portolés (2019) and $\mathrm{Hu}$ and co-researchers (2017) on ECEs' instructional language inside the early classroom. Although the evidence cited above clearly suggests the influence of educators' language on their teaching quality and - subsequently - on children's learning outcomes, it does not yet clarify which linguistic strategies are specifically and predominantly used by ECEs when pedagogically coping with preschool children's educational demands. Moreover, to the best of our knowledge, there are no available comparable studies that had specifically scrutinized these topics in a Latin American ECEs sample, the point from which this study starts.

\section{Research questions}

To explore the above inquiry, we posed two research questions: (1) To what extent is ECEs' most predominant use of directive commands related to giving instructions? and, (2) To what extent do the differential distributions of directive commands emerge in ECEs' speech?

\section{Method}

\section{Design and participants}

A descriptive, cross-sectional and exploratory approach was chosen along 20 participants (ECEs) selected by convenience (all female; $\bar{X}=29.9$ years of age; age range 21 - 40), from 14 state and state-accredited educational institutions. All these institutions are located in two nearby cities in northern Chile. Participants were native speakers of Spanish and held at least a four-year bachelor's degree in early education, worked in the towns where the research was conducted at the time of the study, and had at least one year of professional experience. In addition, no 
participant reported any disqualifying condition that may hinder the data collection and transcription process.

\section{Data gathering}

Audio-recordings of daily ECEs' activities with preschool children were collected during five to seven days within a time period of three to four weeks, following the suggestions on continuous recordings given by Cunningham and coresearchers (2019). The groups taught by our ECEs-participants included three educational levels, with children aged from 24 to 60 months, and approximately 10 to 20 children per each one. The typical audio-recording is 90 to 120 minutes long, and includes one up to three pedagogical activities with a distinguishable beginning, development, and conclusion, which is an expected standard practice for participants' institutions curricular guidelines. The data were processed then by: (a) SPSS v26.0 (IBM Corp., NY, USA) for statistical analysis; (b) Atlas.ti v9.1 (Scientific Software Development, $\mathrm{GmbH}$ ) for selecting the targeted commands within the text and posterior easy accessing; and, (c) Live Transcribe Application for Android (Google and Gallaudet University) for transferring audio to text.

\section{Procedure and data analysis}

Several steps were undertaken to build new data from the pre-existing database, through a selection of a representative portion of the information from the source transcriptions through an inter-rater procedure, in line with: (1) raters independently reviewed 5 cases/transcriptions, randomly chosen; (2) sentences were separated by them according to their expert judgment as belonging to one of the ten considered directive commands from Table 1; (3) then following a blindprocedure, each rater valued the total of extracted sentences from every other rater, resulting in four scores per each sentence/directive command; and, (4) only those sentences that show a high degree of agreement as a recognizable directive command were kept for further analysis and discussion. To classify a sentence as a directive command, it had to consist of a minimum of two and a maximum of twelve words. Also, a limit for extracting sentences from the source transcriptions was set up, with a minimum of 10,000 and a maximum of 12,000 words per rater, and the final sentence number depended on their judgment. This overall procedure was performed by 4 raters who met certain criteria such as similar academic training, expertise, and recognition of the community. Also, to address consistency, accuracy, and reproducibility, two initial meetings were held for criteria unification on coders/experts sharing the same mental schema (e.g.: theoretical background, definitions, and criteria), about the topic under scrutiny.

Descriptive statistics was applied: \%; $\Sigma ; \overline{\mathrm{X}}$; SD; and rater's reliability tested through various agreement coefficients for unique-raters: Cohen's, Fleiss, and Krippendorff's alpha. Also, a post hoc analysis Phi coefficient and Cramer's were considered to check for nominal approximative associations. 


\section{Ethical concerns}

Initial meetings were held and a formal cover letter for the study was sent out. In some cases, permission to record was guaranteed by a pre-existing scientific research agreement with the lead author's institution. Signed consent forms were collected in all cases and the general guidelines of the American Psychological Association (APA) were followed. No compensation was offered to the participants.

\section{Results}

The total number of collected words from our original study was 308,277 $(\overline{\mathrm{X}}=15.413,85 ; \mathrm{SD}=8.455,38)$, through 190 hours of effective audio-recording, and an average of 9.6 hours per participant. From this data, our expert-raters extracted a total number of 34,181 words, which roughly represents $11 \%$ of the total words' source transcriptions, resulting in 1,863 sentences, each tentatively categorized in only one of the ten directive commands as already presented in Table 1 . The number of phrases/directives by each rater was: rater $1(\Sigma 587 ; 31.5 \%)$; rater 2 ( $\Sigma 621$; $33.34 \%)$; rater $3(\Sigma 311 ; 16.41 \%)$; and rater $4(\Sigma 344 ; 18.46 \%)$.

To check the degree of rater's reliability, we first performed Cohen's kappa coefficient for each pair of raters, and then got an overall value through Fleiss's kappa. The results are presented in Table 2, showing only fair significances according to both coefficients' criteria (Landis and Koch 1977). To further confirm this tendency, we applied another coefficient, Krippendorff's alpha, due to its capacity of including any number of raters, missing data, number and type of measurement's levels. Again, a moderate significance was confirmed by this coefficient calibrated to bootstrap at 10,000 with four observers and 11,175 pairs, and following the standards placed out by Hayes and Krippendorff (2007).

\begin{tabular}{|c|c|c|c|c|c|c|}
\hline & \multicolumn{4}{|c|}{ Cohen's $k^{*}$} & Fleiss's & Krippendorff's \\
\hline & Rater 1 & Rater 2 & Rater 3 & Rater 4 & & \\
\hline Rater 1 & 1 & .37 & .22 & .16 & & \\
\hline Rater 2 & & 1 & .41 & .2 & .24 & .24 \\
\hline Rater 3 & & & 1 & .11 & & \\
\hline Rater 4 & & & & 1 & & \\
\hline
\end{tabular}

Table 2. Inter-reliability test for raters' scores

From the data above, rater 2 and rater 3 , and rater 1 and rater 2 show the biggest magnitudes and significances in the given scores, and conversely, greater dispersions were achieved by rater 3 and rater 4 . It was decided to further check whether any of the raters by separate fall outside of this group tendency, which could influence their final degree of agreement. Thus, all punctuations $(1,863 \times 4$ 
$=7,452$ ), were submitted to a nominal associative analysis by Phi and Cramer's V coefficients. We identified again that rater 2 and rater 3 are more likely to similarly score, and rater 3 and rater 4 more dissimilar, following the values given by Akoglu (2018) for these coefficients interpretation (Table 3). However, we decided not to reject any of them, and to conduct a more rigorous selection criterion instead (as aforementioned), for the final validation of sentences into the categories of directive commands.

\begin{tabular}{|c|c|c|c|c|}
\hline & \multicolumn{5}{|c|}{ Phi $\left(r_{\varphi}\right)$ and Cramer's V $\left(\boldsymbol{\varphi}_{c}\right)^{*}$} \\
\hline Raters & $\mathbf{1}$ & $\mathbf{2}$ & $\mathbf{3}$ & $\mathbf{4}$ \\
\hline $\mathbf{1}$ & 1 & $1.35(.45)$ & $.92(.3)$ & $.79(.26)$ \\
\hline $\mathbf{2}$ & & 1 & $1.32(.44)$ & $.91(.3)$ \\
\hline 3 & & & 1 & $.61(.2)$ \\
\hline 4 & \multicolumn{4}{l}{} \\
\hline
\end{tabular}

Table 3. Nominal associations for inter-raters' scores

As follows, we proceeded by extracting only those directive commands that expose a total degree of agreement between raters (4/4 and 3/4), leading to a total number of 691 sentences grouped in: Attentional directives ( $\Sigma 46 ; 14.9 \%)$; Control directives ( $\Sigma 29 ; 4.19 \%)$; Instructional directives ( $\Sigma 213 ; 30.82 \%)$; Generalfeedback ( $\Sigma 5$; $.72 \%) ;$ Approval feedback ( $(54 ; 7.81 \%)$; Disapproval feedback ( $(40 ; 5.78 \%) ;$ Assertive expressions ( $(11 ; 1.59 \%)$; Use of reformulations ( $(115 ; 16.64 \%)$; Request usage ( $(575$; $10.85 \%)$; and Singing $(\Sigma 103 ; 14.9 \%)$. The next figure exposes a simple and clearer view of these proportions.

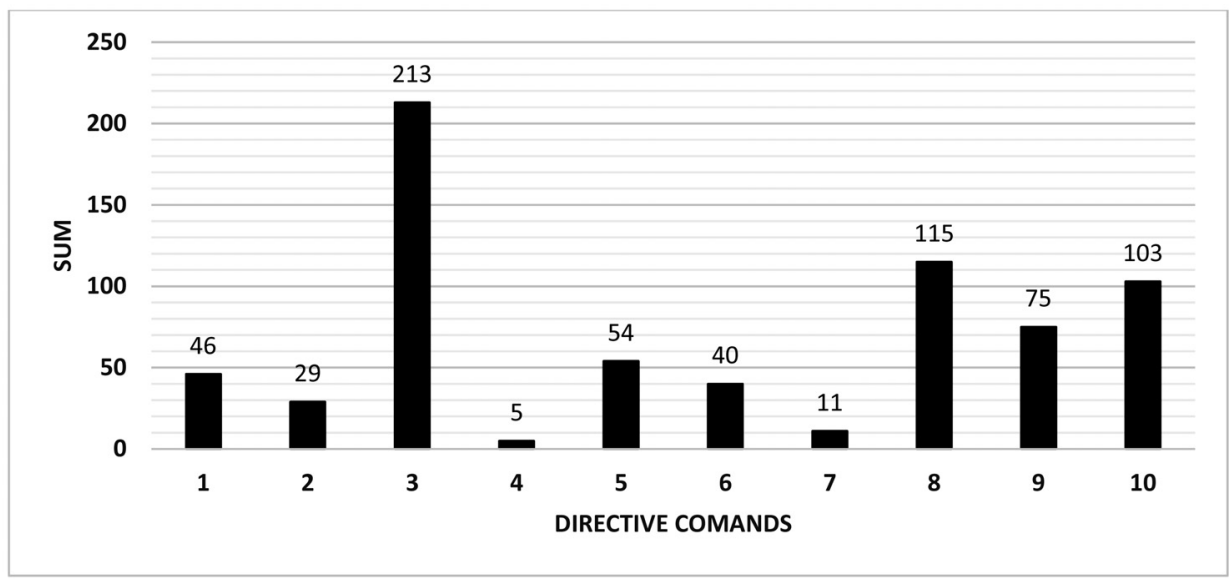

Figure 1. Proportions of directive commands by highest rater's agreement

1-Attentional directives. 2 -Control directives. 3 -Instructional directives. 4-General feedback. 5-Approval feedback. 6 - Disapproval feedback. 7-Assertive expressions. 8 - Use of reformulations. 9 Request usage. 10 - Singing. 
From what is presented above Instructional directives is clearly and by far the directive command that was more frequently detected by our experts.

\section{Discussion}

The initial aim of this study was to check a series of observations drafted out in previous studies about ECEs' speech inside the classroom as being oversaturated by instructions over other kinds of verbal interactions. Our findings are partly in line with what is asserted by Martí and Portolés (2019), by confirming the predominance of imperative forms in ECEs' discourse. So, we can positively respond to our first research question, which suggests instructions are indeed over-present in the daily speech of the ECEs that participated in this study. Additionally, we simultaneously explored to what extent differential distributions equally arise from the ten directive-command categories covered in this study. Following that, differential distributions were simultaneously identified after raters' filtering. These findings shed some light on a typical ECEs' linguistic style more saturated by Instructions, and to a certain degree by Use of reformulations (e.g.: questions), Singing, and other directives or linguistic strategies when managing the classroom and responding to children's educational needs.

\section{Linguistic styles characterizations}

The task of extracting a representative number of any kind of verbal utterances from a continuous speech is a laborious enterprise considering all variabilities, linguistic phrasings, environmental contingencies, and daily situations in which such speech is produced. Thus, the context of the speech is crucial for its understanding, and due to this issue, we decided to reduce this influence and pick up only those directives that pass through a rigorous filtering, and give the study's design-from an expert's point of view - a better falsifiability condition. As a result, the number of collected sentences defined here as directive commands allows us to identify several relevant characteristics that can be pinpointed and exemplified beyond their numerical proportions.

The first three positions by frequency were reached by Instructional' directives (ID), Use of reformulations (R), and Singing (S) respectively. The main goal of this study was to identify the relative proportions of directive commands related to instruction-giving, and as was expected, the highest number belongs to this category. Some brief sentences that exemplify different kinds of typical instructional interventions in our data are:

ID $\rightarrow$ “(...) now we are going to the bathroom (...) we have little time, so let's go, and come back quickly, we must not stay playing or talkingover there (...)" "(....) Go and take it out, listen Camilo, these are for sharing (...)".

“(...) Let's see those hands, frozen! Frozen! Hands up! Hands down! Hands up again! We'll all dance, now turn around (...)". 
A grand variety of instructional directives was observed which evokes the broad and pervasive pedagogic useability of this linguistic style in ECEs' speech by its informational content and usefulness to effectively target an educative goal. In this regard, Haslip and co-researchers (2018) highlight the value in giving clear instructions to children, suggesting its valuable importance as a tool that goes through and beyond just learning and modelling children behaviour. As was already mentioned, the second position in order of sentences density corresponds to a more complex linguistic phenomena that refers to Use of reformulations $(\mathrm{R})$. This kind of directives brings up the ECEs' ability to describe to the child an ongoing educational situation from more than one perspective, for example, by constant questions and descriptions. Here this directive is exemplified by the following:

$$
\mathbf{R} \rightarrow \text { “(...) It doesn't matter if Ilose because, it’s only agame (...)”. }
$$

Singing (S) achieved the third position in the order of frequency, referring in our data to a pedagogic strategy that mostly serves to begin an activity, teach specific contents, call to order, and/or create a suitable atmosphere for further learning. A regular example is the daily morning singing and greetings, as is simplified below:

\section{$\mathrm{S} \rightarrow$ "(...) Pam, pam, the hen is already leaving, pam pam, the chicks go behind (...)".}

In regard of this directive, Gudmundsdottir and Trehub (2017) put a special emphasis on the relevance of singing as a learning tool due to the engagement of various aspects of children development. This opens up new possibilities for further research concerning the specific presence of directive and regulative commands as well as contents in songs and rhymes, and their implicit and explicit educational influence on children.

The next three positions were filled by Request usage (RU), Approval feedback $(\mathrm{AF})$, and Attentional directives (AD) respectively. Firstly, Request usage alludes to adding content/information to a child's situational verbal utterance, exemplified here by this quote:

$$
\begin{aligned}
& \mathrm{RU} \rightarrow \text { “(...) Now you are going to pick nine things that you want, whichever, } \\
& \text { nine flowers, for example, nine butterflies, whatever you want (...)". }
\end{aligned}
$$

The presence of this directive goes along the line of research proposed by Andrews, Van Bergen, and Wyver (2019), about the role of young children understanding their own and other people's mental states (theory of mind), through discussing about them with adults by means of constant questions and inquiries. In our data, ECEs engage in such discourse all the time through a large number of verbal interactions where the focus is posed on asking children about current issues, and requesting contingent and extended answers from them. Next in line, Approval di- 
rectives address ECEs' verbal reinforcements that focus on giving children relevant information related to an ongoing behaviour. These kinds of directives were often identified in phrases such as:

$\mathrm{AD} \rightarrow$ "(....) All the classmates chose to paint, they all painted with tempera and made some very beautiful drawings (...)".

“(...) Youlook very pretty, please sit now on the mat (...)".

The role of these directives may be understood as a tool for stimulating child's speech as well as a desired behavioural outcome. Their relatively high presence can be associated with the importance of positive communication in the form of words that connote children's behaviour along highlighting positive feelings. DeckerWoodrow (2018) emphases this kind of communication as a desirable linguistic style to be developed by a competent ECE, which is then expected to be over-present in their discourse. Instructions with a positive (approval) connotation are a desirable combination that enhance the daily flow of teaching/learning interactions between ECEs and children, which is clearly supported by our data. Meanwhile, Attentional directives evoke ECEs' pedagogical relentless efforts to direct children's attention to an ongoing task, and to put the attentional focus on a situation that needs to be quickly addressed (e.g.: regarding teaching, avoiding mistakes, or - in some extreme situations - dangers). An example is shown below:
$\mathrm{AD} \rightarrow$ “(....) So, you have to listen to me now very well, right? Please pay attention! (...)".
“(....) It is this more beautiful, that the other? Ok, I will lend you this one. Lookat it! (...)".

The identified proportion of attentional directives brings up what was suggested by Degortati (2017) that a precondition for new learning requires reciprocal attention between an adult and a child, involving shared experiences and events of mutual joint interest on both activity and perceptual levels. Consequently, it may be argued that in time this linguistic style will strengthen children's attention and facilitate learning. These data support the ever-present role of cognitive processes, especially attention, in learning and formation of habits, which should be contemplated when pursuing the development of ECEs' professional abilities in competence-based education (Lería Dulčić 2021).

The next three positions in order of frequency were Assertive expression (AE), Control directives (CD), and Disapproval feedback (DF). The first one, Assertive expressions is identified in common phrases such as the following:
$\mathrm{AE} \rightarrow$ “(....) the jaw also helps us smile (...)".
“(....) I am going to tell you that we are a little sad today in our school. Do you remember that when we prayed, we always asked for Uncle Pastor? Uncle Pastor passed away last night (...)". 
These last directives include all of ECEs' verbal utterances that refer to describing a thing or action to children after a question is posed or an action is performed, in this way aimed at correcting or re-directing their behaviour. In the case of Control directives, they are most visible in examples such as:

$\mathrm{CD} \rightarrow$ “(...) They are not playing with you now. Don't you understand? Leave themalone (...)".

"(....) Sofia: why do you keep crying, daughter? Leave it there and please stop crying (...)".

This kind of directives may also be understood under the term 'prohibitive commands' as is described by Aikhenvald (2010), often involving negative verbs meaning 'stop' or 'leave'. This lower density goes along with our prior findings, and the low proportion of emotion-related words with a negative connotation (Lería Dulčić et al. in press) that were identified in ECEs' speech. This represents a linguistic competence liable to strengthening and empowering the pedagogical influence of negative-connoting words in posing limits to children. For instance, a higher density of commands that limit children's behaviour may be welcomed, along with a high density of positive and approval feedbacks focused on motivating children, both supported by our data. Their relevance likewise lays upon what has recently been argued by Siegal and Francis (2019), about the fostering of assertive techniques that may involve negative reinforcement and deprivation of privileges. Finally, Disapproval feedbacks are unexpectedly and rarely found across the original transcriptions, which may be attributed to the same reasons presented above. The next example may help to figure out this dynamic:

\section{$\mathrm{DF} \rightarrow$ " (....) if you are fighting for this, we will take this game home. I am not asking you! (...)".}

The last position was reached by the directive command General feedback (GF) with a negligible number of identified sentences, which may be attributed to the broad and vague nature of its definition.

\section{Limitations}

Our study offers a panoramic view of some tendencies in ECEs' disciplinary speech, suggesting some facets that may be considered in order to continue this line of research, but also to improve ECEs' verbal competency. First and foremost, our findings refer to an expert's perspective on the study subject, which should, ideally, be corroborated by other methodological designs in the future. Secondly, many of the cached directives are conceptually and linguistically very close to each otherfor example, the case of the attentional and instructional directives, and/or control directives and disapproval feedback. This may represent a difficulty that concerns 
raters' ability to differentiate them, which we partially resolved by applying an exclusive criterion of higher agreement. However, future research must readdress this issue with stricter operationalizable variables and more specific conceptual definitions for each categorical directive. Lastly, further studies may consider the educational context as an intervenient variable where ECEs' professional language is set up, through - for example - the specific kind of ongoing educational practices, exercises, plays, contents, and/or characteristic of the learning place where ECEs speech is expressed (e.g.: classroom vs yard).

\section{Conclusions}

The relevancy of adults' verbal interactions as having a shaping effect on children makes explicit the necessity of exploring specific language characteristics and uses of those who directly work with them. Thus, we were able to identify the relative proportions of several distinctive directive commands as they are used by ECEs in regular educational practices with preschool children. The findings suggest a predominance of instructional directives, followed by use of reformulation and singing. Although these data are prone to several changeable conditions from the environments in which our ECEs work, they represent a well-defined tendency that may be explored beyond.

At last, current trends in early childhood education have progressively accepted the necessity of refining ECEs' technical language to properly address children's learning needs, so its exploration may guide curricular policies on pivotal dimensions of their professional development as the verbal competence is. This is especially pertinent when considering what is argued by Johnson (2018) that a wellbased teacher practice requires the enaction of a theoretical and a consistent instructional practice. Our findings advise in favour of working on the diversification of ECEs' linguistic scaffolds through various topics that emanate from the studied concepts that are equally closely implied, for instance: growth of technical vocabulary, appropriate lexical choices, creating meanings, and/or a proper response to age sense-making. We hope these findings will invigorate the interest for this line of research, so as to foster ECEs' language proficiency and - generally speaking strengthen their formative experience.

\section{Acknowledgements}

We wish to thank the Center for Postgraduate Studies of the University of $\mathrm{Za}$ greb, in particular the "Language and Cognitive Neuroscience" doctoral program, and the school communities that took part in this research. 


\section{References}

Aikhenvald, Alexandra Y. (2010). Imperatives and Commands. Oxford University Press Inc., New York

Akoglu, H. (2018). User's guide to correlation coefficients. Turkish Journal of Emergency Medicine, 18(3): 91-93, https://doi.org/10.1016/j.tjem.2018.08.001

Andrews, R., Van Bergen, P., and S. Wyver (2019). Use of Mental State Language during Educator-Child and Mother-Child Conversations about the Past and Future. Early Education and Development, 1-16, https://doi.org/10.1080/10409289.2019.1689772

Aquino, Fabiola de Sousa Braz, and Nádia Maria Ribeiro Salomão (2011). Intencionalidade comunicativa e atenção conjunta: uma análise em contextos interativos mãebebê. Psicologia: Reflexão e Crítica 24(1): 107-115, https://doi.org/10.1590/S0102-79722011000100013

Aquino, Fabiola de Sousa Braz, and Nádia Maria Ribeiro Salomão (2005). Estilos diretivos maternos apresentados a meninos e meninas. Estudos de Psicologia (Natal) 10(2): 223230, https://doi.org/10.1590/S1413-294X2005000200009

Cazden, Courtney B. (2001). Classroom discourse: The language of teaching and learning (2nd ed.). Portsmouth, NH: Heinemann

Chen, Jennifer J., and Xiaoting Liang (2016). Teachers' Literal and Inferential Questions and Children's Responses: A Study of Teacher-Child Linguistic Interactions During Whole-Group Instruction in Hong Kong Kindergarten Classrooms. Early Childhood Education Journal 45(5): 671-683, https://doi.org/10.1007/s10643-016-0807-9

Chen, Fay. (2017). Instructional Language Use in Environmental Science Classroom. English Language Education 8: 57-78. In Tsou, S.-M. Kao (eds.). English as a Medium of Instruction in Higher Education. Springer Nature Singapore Pte. Ltd, https://doi.org/10.1007/978-981-10-4645-2_4

Christie, Frances (2005). The language of classroom interaction and learning. In Researching Language in Schools and Communities Functional Linguistic Perspectives. Edited by Len Unsworth. CASSELL: London and Washington

Ciesielski, E. J. M., and N. A. Creaghead (2020). The Effectiveness of Professional Development on the Phonological Awareness Outcomes of Preschool Children: A Systematic Review. Literacy Research and Instruction 59(2): 121-147, https://doi.org/10.1080/19388071.2019.1710785

Cunningham, Jennifer. E., Kathleen. N. Zimmerman, Jennifer R. Ledford, and Ann P. Kaiser (2019). Comparison of measurement systems for collecting teacher language data in early childhood settings. Early Childhood Research Quarterly 49(4): 164-174, https://doi.org/10.1016/j.ecresq.2019.06.008

Decker-Woodrow, Lauren (2018). The Relationship Between Internal Teacher Profiles and the Quality of Teacher-Child Interactions in Prekindergarten. Journal of Research in ChildhoodEducation 32(1): 32-51, https://doi.org/10.1080/02568543.2017.1393030

Degotardi, Sheila (2017). Joint attention in infant-toddler early childhood programs: Its dynamics and potential for collaborative learning. Contemporary Issues in Early Childhood 18(4): 409-421, https://doi.org/10.1177/1463949117742786 
Farrow, Jean M., Wasik, Barbara A., and Annemarie H. Hindman (2020). Exploring the unique contributions of teachers' syntax to preschoolers' and kindergarteners' vocabulary learning. Early Childhood Research Quarterly 51: 178-190, https://doi.org/10.1016/j.ecresq.2019.08.005

Fischer, Kerstin (2010). Beyond the sentence: Constructions, frames and spoken interaction. Grammar and Interaction 2(2): 185-207, https://doi.org/10.1075/cf.2.2.03fis

Gerde, Hope K., Steven J. Pierce, Kyungsook Lee, and Laurie A. Van Egeren (2018). Early childhood educators' Self-Efficacy in Science, Math, and Literacy Instruction and Science Practice in the Classroom. Early Education and Development 29(1): 70-90, https://doi.org/10.1080/10409289.2017.1360127

Gudmundsdottir, Helga R., and Sandra Trehub (2017). Adults recognize toddlers' song renditions. Psychology of Music 46(2): 281-291, https://doi.org/10.1177/0305735617711762

Halliday, M. A. K. (1976) System and Function in Language, Gunther R. Kress (ed.). London: Oxford University Press

Halliday, M. A. K., and C. M. I. Matthiessen (2014). An Introduction to Functional Grammar. London: Routledge

Haslip, Michael J., Ayana Allen-Handy, and Leona Donaldson (2018). How urban ECEs used positive guidance principles and improved teacher-child relationships: a socialemotional learning intervention study. Early Child Development and Care 190(7): 971990, https://doi.org/10.1080/03004430.2018.1507027

Hayes, A. F., and K. Krippendorff (2007). Answering the call for a standard reliability measure for coding data. Communication Methods and Measures 1(1): 77-89, https://doi.org/10.1080/19312450709336664

Hinojosa, José A., Eva M. Moreno, and Pilar Ferré (2019). Affective neurolinguistics: towards a framework for reconciling language and emotion. Language, Cognition and Neuroscience 35(7): 813-839, https://doi.org/10.1080/23273798.2019.1620957

Hu, Jiangbo, Jane Torr, Sheila Degotardi, and Feifei Han (2017). Educators' production of commanding language to direct infants' behaviour: relationship to educators' qualifications and implications for language learning opportunities. Early Years 39(2): 1-15, https://doi.org/10.1080/09575146.2017.1368008

Johnson, Karen E. (2018). Studying language teacher cognition: Understanding and enacting theoretically consistent instructional practices. Language Teaching Research 22(3): 259-263, https://doi.org/10.1177/1362168818772197

Justice, Laura M., Hui Jiang, and Katherine Strasser (2018). Linguistic environment of preschool classrooms: What dimensions support children's language growth? Early Childhood Research Quarterly 42: 79-92, https://doi.org/10.1016/j.ecresq.2017.09.003

Kalinowski, Eva, Franziska Egert, Anna Gronostaj, and Miriam Vock (2020). Professional development on fostering students' academic language proficiency across the curriculum-A meta-analysis of its impact on teachers' cognition and teaching practices. Teaching and Teacher Education 88: 102971, https://doi.org/10.1016/j.tate.2019.102971 
King, Elizabeth, and Karen M. La Paro (2018). Teachers' Emotion Minimizing Language and Toddlers' Social Emotional Competence. Early Education and Development 29(8): 989-1003, https://doi.org/10.1080/10409289.2018.1510214

Landis, Richard J., and Gary G. Koch (1977) The measurement of observer agreement for categorical data. Biometrics 33: 159-174, https://doi.org/10.2307/2529310

Lería Dulčić, Francisco José, Roxana Nora Acosta Peña and Patricia Ester Sasso Orellana. (in press). Socio-affective words production by early childhood educators: lexical density, clusters, and predictors. Revista Electrónica de Investigación Educativa 23

Lería Dulčić, Francisco José (2021). The practice of silence as an educational tool: guidelines for competence-based education. Educação e Pesquisa 47(e224651): 1-18, https://doi.org/10.1590/S1678-4634202147224651

Markussen-Brown, Justin, Carsten B. Juhl, Shayne B. Piasta, Dorthe Bleses, Anders Højen, and Laura M. Justice (2017). The effects of language- and literacy-focused professional development on early educators and children: A best-evidence meta-analysis. Early Childhood Research Quarterly 38: 97-115, https://doi.org/10.1016/j.ecresq.2016.07.002

Martí, Otilia, and Laura Portolés (2019). Is Teacher Talk for Very Young Language Learners Pragmatically Tuned? Directives in Two EAL Classrooms. Investigating the Learning of Pragmatics across Ages and Contexts 34: 87-122, https://doi.org/10.1163/9789004409699_006

Martínez-Insua, A. (2004). Existential there-constructions in Contemporary British English: a corpus-driven analysis of their use in speech and writing. Munchen: Lincom Europa. In Fontaine, L., T. Bartlett, and O'Grady, G. eds. (2013). Systemic Functional Linguistics: Exploring Choice. University Printing House, Cambridge CB2 8BS, United Kingdom

Matthiessen, Christian M. I. M., Kazuhiro Teruya, and Marvin Lam (2010). Key Terms in Systemic Functional Linguistics. Continuum International Publishing Group: London - New York

Medina, Carol, and David M. Sobel (2019). Caregiver-child interaction influences causal learning and engagement during structured play. Journal of Experimental Child Psychology 189(104678): 1-12, https://doi.org/10.1016/j.jecp.2019.104678

Nunes, Laísy de Lima, and Fabíola de Sousa Braz Aquino (2014). Habilidade de comunicação intencional de bebês: o que pensam as mães? Psicologia: Teoria e Pesquisa 30(4): 363-372

Oliveira, Keilla R., Nádia M. Salomão, and Fabiola D. S. Aquino (2016). Desenvolvimento da linguagem na primeira infância e estilos linguísticos dos educadores. Avances en Psicología Latinoamericana 34(3): 457-472, https://doi.org/10.12804/apl34.3.2016.02

Ornstein, Peter A., and Jennifer L. Coffman (2020). Toward an Understanding of the Development of Skilled Remembering: The Role of Teachers' Instructional Language. Current Directions in Psychological Science, 1-8, https://doi.org/10.1177/0963721420925543

Piasta, Shayne B., Somin Park, Kristin S. Farley, Laura M. Justice, and Ann A. O'Connell (2019). Early childhood educators' knowledge about language and literacy: Associations with practice and children's learning, Dyslexia 26(2): 137-152. 
https://doi.org/10.1002/dys.1612

Pizarro, P., N. Peralta, C.Audisio, F. Mareovich, F.Alam, and C. Rosemberg(2019). Ellenguaje de las educadoras y de los niños y niñas. Pensamiento Educativo: Revista de Investigación Educacional Latinoamericana, 56: 1-18, https://doi.org/1010.7764/PEL.56.1.2019.6

Prediger, Susan. (2019). Investigating and promoting teachers' expertise for language-responsive mathematics teaching. Mathematics Education Research Journal, 31: 367-392, https://doi.org/10.1007/s13394-019-00258-1

Reyes, Lucía, Roberto Arístegui, Mariane Krause, Katherine Strasser, Alemka Tomicic, Nelson Valdés, Caroline Altimir, Ivonne Ramírez, Guillermo de la Parra, Paula Dagnino, Orietta Echávarri, Oriana Vilche, and Perla Ben-Dov. (2008). Language and Therapeutic Change: A Speech Acts Analysis. Psychotherapy Research 18(3): 355-362, https://doi.org/10.1080/10503300701576360

Schachter, Rachel E., Caitlin F. Spear, Shayne B. Piasta, Laura M. Justice, and Jessica A. R. Logan (2016). ECEs' knowledge, beliefs, education, experiences, and children's language- and literacy-learning opportunities: What is the connection? Early Childhood Research Quarterly 36: 281-294, https://doi.org/10.1016/j.ecresq.2016.01.008

Siegal, M., and R. Francis (2019). Top of Form Bottom of Form

Socialization and moral development. In Morrison, Delmont C. ed. Organizing Early Experience Imagination and Cognition in Childhood. 1st Edition. CRC Press: Taylor and Francis Group. P. 17-32

Simões de Oliveira, Keilla Rebeka, Fabíola de Sousa Braz-Aquino, and Nádia Maria Ribeiro Salomão (2016). Desenvolvimento da linguagem na primeira infância e estilos linguísticos dos educadores. Avances en Psicología Latinoamericana 34(3): 457-472

Subsecretary of Initial education [SIE] (2018). Nuevas Bases curriculares de la educación parvularia. Santiago, Ministerio de educación, Gobierno de Chile, 136p. Retrieved from https://parvularia.mineduc.cl/wp-content/uploads/sites/34/2018/03/Bases_Curriculares_Ed_Parvularia_2018.pdf

SIE (2019). Lenguaje Verbal Orientaciones Técnico-Pedagógicas para el Nivel de Educación Parvularia. Santiago, Ministerio de educación, Gobierno de Chile, 19p. Retrieved from https://parvularia.mineduc.cl/wp-content/uploads/sites/34/2019/06/verbal-alta_c.pdf

Torr, Jane, and Lien Pham (2016). Educator Talk in Long Day Care Nurseries: How Context Shapes Meaning. Early Childhood Education Journal 44: 245-254, https://doi.org/10.1007/s10643-015-0705-6

Wasik, Barbara A., and Jill L. Jacobi-Vessels (2017). Word Play: Scaffolding Language Development Through Child-Directed Play. Early Childhood Educ Journal 45: 769-776, https://doi.org/10.1007/s10643-016-0827-5

Van Loon, Mariëtte H., and Claudia M. Roebers (2020). Using feedback to improve monitoring judgment accuracy in kindergarten children. Early Childhood Research Quarterly 53: 301-313, https://doi.org/10.1016/j.ecresq.2020.05.007 


\section{Preplavljuju li upute predškolsku učionicu? Uporaba uputa naspram zapovijedi u odgoju djece predškolske dobi}

Upute temeljni su dio jezičnih stilova koje rabe odgajateljice rane i predškolske dobi tijekom mnoštva interakcija kojima neprestano nastoje da djecu vode u postizanju odgojnog cilja. Međutim, malo je do sada pozornosti bilo posvećeno proučavanju uporabe i relativne omjere/proporcije izgovorenih direktiva u njihovom dnevnom govoru. Teorijskom podlogom temeljenom na funkcionalnoj lingvistici, svrha je ovog istraživanja da se identificira iz velike baze podataka odgajateljičinih izgovorenih naredbi kako bi se provjerila njihova distribucija i učestalost u odnosu na druge zapovjedi koje su jednako važne za njihov rad u usporedbi s drugim verbalnim modalitetima koje su jednako važne za njihov pedagoški rad, kao npr.: naredbe, izreke, povratne informacije, pitanja i dr. Na uzorku od 20 sudionika, prikupljeni su audio-zapisi tijekom njihovih dnevnih rutina u radu s djecom, te je odabran velik broj rečenica koje su bile svrstane prema kategoriji direktiva - deset u ovom studiju. Na temelju dobivenih podataka, uočeno je da su najučestalije zapovjedi i upute, a nakon njih slijede uporabe reformulacije i pjevanje, među drugim direktivama. Zaključujemo da je odgajateljicama rane i predškolske dobi ključno imati uvid u jezični stil koji najčešće koriste u svrsi donošenja učinkovitih odluka kako bi se postigao željeni odgojni cilj, i na taj način, podržavao proces učenja. Kratki osvrt na opseg ovih rezultata je predstavljen uvažavajući buduća istraživanja i njihov doprinos visokoškolskom obrazovanju odgajateljica rane i predškolske dobi.

Keywords: language behaviour, early childhood education, teachers' skills, educational quality, language instruction

Ključne riječi: jezično ponašanje, obrazovanje u ranom djetinjstvu, vještine odgajateljica, kvaliteta obrazovanja, poduka jezika 